\title{
The Impact Of Internship Training Year On Nurse Interns' Clinical Skills Acquisition In Intensive Care Units At Main Mansoura University Hospital.
} By

\author{
Asmaa Mustafa Esmael1 ${ }^{1}$, Hala G. Elatroush.D.N.Sc ${ }^{2}$. \\ And Neamat M. El-Sayed ${ }^{3}$, D.N.Sc ${ }^{2}$ \\ 1,2Department of Nursing Administration Mansoura University, \\ 3Department of Nursing Administration Damanhour University
}

\begin{abstract}
Introduction: Internship program is considered to be the most effective means of increased the novice practitioner's confidence and competence and enhancing care setting, acquisition of technical and managerial skills. It is the most critical period in the professional life of the graduate. Aim of the study: assess the impact of internship training experience on nurse intern skills acquisition. Design: descriptive design. Setting: Intensive care units at Mansoura University hospital. Subjects and methods: The study sample composed of 130 nurse interns. Data was collected by using observation checklist for nurse interns (Orientation Professional Profile Checklist). Results: revealed that there was statistically significant improvement in both technical and managerial skills after two months internship training experience $(\mathrm{P}<0.05)$.

Recommendation: The findings of the present study concluded that, there was a highly statistical significant difference in the intern nurse skills according to all technical and managerial skills after two months internship training experience. However, there was not statistical significant improvement according to data collection items after two months internship training experience. Therefore, considerable attention and more efforts are required to maximize the intern's benefits from the internship training period. Every nurse intern should be aware of her/his role during internship training program from job description and log book must be including nurse intern job description.
\end{abstract}

Key words: Internship program- nurse interns -skills acquisition.

\section{Introduction:}

Continuous increase in intensity, complexity of patient care in a period of rapidly developing technology, as well as the financial drain on patients, combined to the shortage of critical care nurses, and the need to provide quality health care at a limited cost have created multiple challenges for hospitals and consumers, and increased the demand for skilled nurses [1] Current nursing literature emphasizes the importance of preparing nurses of the future to have a wide range leadership and clinical skills with the ability to function in a variety of settings ${ }^{[2]}$.

Internship program means a form of experiential learning that integrates knowledge and theory learned in the classroom with 
Asmaa Mustafa Esmael1..at.el.

practical application and skills development in a practical setting $^{[3]}$.

Internship program help nurse interns to gain a valuable careerrelated experience, expanded knowledge of career options in the field, increase confidence in skills and abilities, develop a clearer picture of personal career direction $^{[4]}$.

Nurse intern student is the person who still within the framework of formal and accountable post academic education where cognitive, attitudinal and, psychomotor skills are initially mastered. Nurse intern is the student who entered the internship program; their training was planned ${ }^{[5] .}$

So that, there is a need to evaluate internship training year and ways in which it can be improved in seriously areas as intensive care unit that require highly skilled nursing care that is comprehensive as well as specialized.

The aim of the current study is to assess the impact of internship training year on the skill acquisition of nurse intern in intensive care unit at Main Mansoura University hospital.

\section{Subjects and methods:}

The subjects of this study consist of nurse interns who are graduated in academic years 2011-2012, and practice their training in intensive care units at Main Mansaura University hospital. Their total number was 399 nurse interns, 17 nurse interns excluded because they spent their training under supervision of other faculties. Sample size was 130 nurse interns. Equation for determining sample size. At $95 \%$ confidence power of the study.

$\mathrm{N} \times \mathrm{P}(1-\mathrm{P})$

$$
\mathrm{n}=\frac{\text { Steven Thimpsone equation }}{\{((\mathrm{N}-1 \times(\mathrm{d} 2 / \mathrm{Z} 2))+\mathrm{P}(1-\mathrm{P})}
$$
$\mathrm{n}=$ Sample size

$\mathrm{N}=$ Total society size $=382$

$\mathrm{d}=$ error percentage $=(0.05)$

$\mathrm{P}=$ percentage of availability of the character and objectivity $=(0.1)$

$\mathrm{Z}=$ the corresponding standard class of significance $95 \%=(1.96)$

The data of the study were collected by using Orientation Professional Profile Check List modified by researcher based on Orientation Professional Profile questionnaire ${ }^{[6]}$ to determine the clinical skills of nurse interns using pre-and post test.

It consists of two parts:

The 1st part: Personal Data of intern nurse as name, age, and marital status.

The 2nd part: Orientation Professional Profile Check List includes two groups: Technical skills (14 categories with 95 items) 
and managerial skills (4categories with 31 items).

Scoring system: According to Likart scale, the items observed to be done completely was scored" 2", done incompletely was scored" 1 " and not done was scored " 0 ". The clinical skills acquisition divided into

- Less than $50 \%$ score considered as low clinical skills acquisition.

- $50-75 \%$ score considered as moderate clinical skills acquisition.
- More than $75 \%$ score considered as high clinical skills acquisition. ${ }^{[7]}$.

\section{Statistical Analysis}

Statistical analysis was done by using SPSS software (Statistical Package for the Social Sciences). For quantitative data, the range, mean and standard deviation were calculated. For qualitative data, Chi-square test $\chi 2$. Paired t-test, Wilcox on Signed Ranks Test was used. Significance was adopted at $\mathrm{p}<0.05$.

\section{Results:}

Table (1): Distribution of the studied internship students at ICUs by their demographic characteristics $(n=130)$.

\begin{tabular}{|c|c|c|}
\hline \multirow{2}{*}{ Variables } & \multicolumn{2}{|c|}{$\begin{array}{l}\text { The studied internship students at ICUs } \\
\qquad(\mathrm{n}=130)\end{array}$} \\
\hline & $\mathbf{N}$ & $\%$ \\
\hline \multicolumn{3}{|l|}{-Age (years) } \\
\hline$<22$ & 34 & 26.2 \\
\hline 22- & 60 & 46.2 \\
\hline 23- & 21 & 16.1 \\
\hline$\geq 24$ & 15 & 11.5 \\
\hline Range & $20-23$ & \\
\hline $\operatorname{Mean} \pm$ SD & $21.66 \pm 0.90$ & \\
\hline \multicolumn{3}{|l|}{-Marital status } \\
\hline Single & 69 & 53.1 \\
\hline Married & 61 & 46.9 \\
\hline
\end{tabular}


Table (2): Distribution of the studied internship students at ICUs by their technical skills acquisition grades pre and post two months internship training experience $(n=130)$.

\begin{tabular}{|c|c|c|c|c|c|c|}
\hline \multirow{3}{*}{ Technical skill degrees } & \multicolumn{4}{|c|}{$\begin{array}{c}\text { Skill acquisition of the studied } \\
\text { internship students at ICUs(n=130) }\end{array}$} & \multirow[t]{3}{*}{$x^{2}$} & \multirow[t]{3}{*}{$\mathbf{P}$} \\
\hline & \multicolumn{2}{|c|}{ Pre } & \multicolumn{2}{|c|}{ Post } & & \\
\hline & $\mathbf{n}$ & $\%$ & $\mathbf{n}$ & $\%$ & & \\
\hline $\begin{array}{l}\text { 1-Management } \\
\text { gastrointestinal output } \\
\text {-Low } \\
\text {-Moderate } \\
\text {-High }\end{array}$ & $\begin{array}{c}117 \\
12 \\
1\end{array}$ & $\begin{array}{c}90.0 \\
9.2 \\
0.8\end{array}$ & $\begin{array}{l}12 \\
96 \\
22\end{array}$ & $\begin{array}{c}9.2 \\
73.8 \\
16.9\end{array}$ & 169.97 & $0.0001 *$ \\
\hline $\begin{array}{l}\text { 2-Assessing nutritional needs } \\
\text {-Low } \\
\text {-Moderate } \\
\text {-High }\end{array}$ & $\begin{array}{l}51 \\
52 \\
27\end{array}$ & $\begin{array}{l}39.2 \\
40.0 \\
20.8\end{array}$ & $\begin{array}{l}27 \\
65 \\
38\end{array}$ & $\begin{array}{l}20.8 \\
50.0 \\
29.2 \\
\end{array}$ & 10.69 & $0.005^{*}$ \\
\hline $\begin{array}{l}\text { 3-Management of genitourinary } \\
\text { output } \\
\text {-Low } \\
\text {-Moderate } \\
\text {-High }\end{array}$ & $\begin{array}{c}127 \\
2 \\
1 \\
\end{array}$ & $\begin{array}{c}97.7 \\
1.6 \\
0.8 \\
\end{array}$ & $\begin{array}{c}4 \\
83 \\
43 \\
\end{array}$ & $\begin{array}{c}3.1 \\
63.8 \\
33.1 \\
\end{array}$ & 232.77 & $0.0001 *$ \\
\hline $\begin{array}{l}\text { 4- Blood loss assessment } \\
\text {-Low } \\
\text {-Moderate } \\
\text {-High }\end{array}$ & $\begin{array}{c}104 \\
22 \\
4\end{array}$ & $\begin{array}{c}80.0 \\
16.9 \\
3.1 \\
\end{array}$ & $\begin{array}{l}84 \\
19 \\
27\end{array}$ & $\begin{array}{l}64.6 \\
14.6 \\
20.8 \\
\end{array}$ & 19.41 & $0.0001 *$ \\
\hline $\begin{array}{l}\text { 5- Culture collection } \\
\text {-Low } \\
\text {-Moderate } \\
\text {-High }\end{array}$ & $\begin{array}{l}49 \\
44 \\
37\end{array}$ & $\begin{array}{l}37.7 \\
33.8 \\
28.5\end{array}$ & $\begin{array}{c}0 \\
4 \\
126 \\
\end{array}$ & $\begin{array}{c}0 \\
3.1 \\
96.9 \\
\end{array}$ & 130.93 & $0.0001 *$ \\
\hline $\begin{array}{l}\text { 6- Specimen testing } \\
\text {-Low } \\
\text {-Moderate } \\
\text {-High }\end{array}$ & $\begin{array}{l}64 \\
25 \\
41 \\
\end{array}$ & $\begin{array}{l}49.2 \\
19.2 \\
31.5 \\
\end{array}$ & $\begin{array}{l}39 \\
18 \\
73 \\
\end{array}$ & $\begin{array}{l}30.0 \\
13.8 \\
56.1 \\
\end{array}$ & 16.19 & $0.0003 *$ \\
\hline $\begin{array}{l}\text { 7- Monitoring the physiological } \\
\text { parameters } \\
\text {-Low } \\
\text {-Moderate } \\
\text {-High }\end{array}$ & $\begin{array}{c}21 \\
104 \\
5\end{array}$ & $\begin{array}{c}16.2 \\
80.0 \\
3.8\end{array}$ & $\begin{array}{c}4 \\
113 \\
13\end{array}$ & $\begin{array}{c}3.1 \\
86.9 \\
10.0\end{array}$ & 15.49 & $0.0004 *$ \\
\hline $\begin{array}{l}\text { 8-Parenteral fluid administration } \\
\text {-Low } \\
\text {-Moderate } \\
\text {-High }\end{array}$ & $\begin{array}{l}18 \\
74 \\
38\end{array}$ & $\begin{array}{l}13.8 \\
56.9 \\
29.2\end{array}$ & $\begin{array}{c}9 \\
78 \\
43\end{array}$ & $\begin{array}{c}6.9 \\
60.0 \\
33.1\end{array}$ & 3.41 & 0.181 \\
\hline $\begin{array}{l}\text { 9- Assisting patient to } \\
\text { maintain optimum mobility } \\
\text {-Low } \\
\text {-Moderate } \\
\text {-High }\end{array}$ & $\begin{array}{c}23 \\
99 \\
8\end{array}$ & $\begin{array}{c}17.7 \\
76.1 \\
6.1\end{array}$ & $\begin{array}{c}1 \\
104 \\
25\end{array}$ & $\begin{array}{c}0.8 \\
80.0 \\
19.2\end{array}$ & 29.05 & $0.0001 *$ \\
\hline
\end{tabular}

*Significant $(\mathrm{P}<0.05)$ 
The impact of internship training year on nurse interns' etc....

\begin{tabular}{|c|c|c|c|c|c|c|}
\hline \multirow[t]{3}{*}{ Technical skills degrees } & \multicolumn{4}{|c|}{$\begin{array}{l}\text { Skill acquisition of the studied } \\
\text { internship students at ICUs } \\
(n=130)\end{array}$} & \multirow[t]{3}{*}{$x^{2}$} & \multirow[t]{3}{*}{$\mathbf{P}$} \\
\hline & \multicolumn{2}{|c|}{ Pre } & \multicolumn{2}{|c|}{ Post } & & \\
\hline & $\mathrm{n}$ & $\%$ & $\mathrm{n}$ & $\%$ & & \\
\hline $\begin{array}{l}\text { 10- Assisting in daily hygienic procedures } \\
\text {-Low } \\
\text {-Moderate } \\
\text {-High }\end{array}$ & $\begin{array}{l}95 \\
27 \\
8\end{array}$ & $\begin{array}{c}73.1 \\
20.8 \\
6.1\end{array}$ & $\begin{array}{c}4 \\
17 \\
109\end{array}$ & $\begin{array}{l}3.1 \\
13.1 \\
83.8\end{array}$ & 173.11 & $0.0001 *$ \\
\hline $\begin{array}{l}\text { 11- Prevention of nosocomial infection } \\
\text {-Low } \\
\text {-Moderate } \\
\text {-High }\end{array}$ & $\begin{array}{l}97 \\
26 \\
7\end{array}$ & $\begin{array}{c}74.6 \\
20.0 \\
5.4\end{array}$ & $\begin{array}{c}78 \\
51 \\
1\end{array}$ & $\begin{array}{c}60.0 \\
39.2 \\
0.8 \\
\end{array}$ & 14.68 & $0.0006 *$ \\
\hline $\begin{array}{l}\text { 12- Respiratory care } \\
\text {-Low } \\
\text {-Moderate } \\
\text {-High }\end{array}$ & $\begin{array}{c}94 \\
32 \\
4 \\
\end{array}$ & $\begin{array}{l}72.3 \\
24.6 \\
3.1 \\
\end{array}$ & $\begin{array}{l}65 \\
52 \\
13 \\
\end{array}$ & $\begin{array}{l}50.0 \\
40.0 \\
10.0\end{array}$ & 14.82 & $0.0006^{*}$ \\
\hline $\begin{array}{l}\text { 13- Special equipment } \\
\text {-Low } \\
\text {-Moderate } \\
\text {-High }\end{array}$ & $\begin{array}{c}124 \\
6 \\
0\end{array}$ & $\begin{array}{c}95.4 \\
4.6 \\
0\end{array}$ & $\begin{array}{c}103 \\
26 \\
1\end{array}$ & $\begin{array}{c}79.2 \\
20.0 \\
0.8\end{array}$ & 15.44 & $0.0004 *$ \\
\hline $\begin{array}{l}\text { 14-Medication administration } \\
\text {-Low } \\
\text {-Moderate } \\
\text {-High }\end{array}$ & $\begin{array}{c}9 \\
53 \\
68\end{array}$ & $\begin{array}{l}6.9 \\
40.8 \\
52.3\end{array}$ & $\begin{array}{c}1 \\
52 \\
77\end{array}$ & $\begin{array}{l}0.8 \\
40.0 \\
59.2\end{array}$ & 6.97 & $0.031^{*}$ \\
\hline
\end{tabular}

*Significant $(\mathrm{P}<0.05)$

Table (3): Distribution of the studied internship students at ICUs by their managerial skills grades pre and post two months internship training experience $(n=130)$.

\begin{tabular}{|c|c|c|c|c|c|c|}
\hline \multirow[t]{3}{*}{ Managerial skill degrees } & \multicolumn{4}{|c|}{$\begin{array}{c}\text { Skill acquisition of the studied } \\
\text { internship students at } \\
\text { ICUs(n=130) }\end{array}$} & \multirow[t]{3}{*}{$\chi^{2}$} & \multirow[t]{3}{*}{$\mathbf{P}$} \\
\hline & \multicolumn{2}{|c|}{ Pre } & \multicolumn{2}{|r|}{ Post } & & \\
\hline & $\mathbf{n}$ & $\%$ & $\mathbf{n}$ & $\%$ & & \\
\hline $\begin{array}{l}\text { 1- Data collection and analysis } \\
\text {-Low } \\
\text {-Moderate } \\
\text {-High }\end{array}$ & $\begin{array}{l}123 \\
3 \\
4\end{array}$ & $\begin{array}{l}94.6 \\
2.3 \\
3.1 \\
\end{array}$ & $\begin{array}{l}126 \\
0 \\
4\end{array}$ & $\begin{array}{l}96.9 \\
0 \\
3.1 \\
\end{array}$ & 3.04 & 0.219 \\
\hline $\begin{array}{l}\text { 2- Planning of nursing care } \\
\text {-Low } \\
\text {-Moderate } \\
\text {-High }\end{array}$ & $\begin{array}{l}126 \\
4 \\
0\end{array}$ & $\begin{array}{l}96.9 \\
3.1 \\
0\end{array}$ & $\begin{array}{l}116 \\
10 \\
4\end{array}$ & $\begin{array}{l}89.2 \\
7.7 \\
3.1\end{array}$ & 6.98 & $0.030^{*}$ \\
\hline $\begin{array}{l}\text { 3- Implementation of care plan } \\
\text {-Low } \\
\text {-Moderate } \\
\text {-High }\end{array}$ & $\begin{array}{l}9 \\
29 \\
92 \\
\end{array}$ & $\begin{array}{l}6.9 \\
22.3 \\
70.8 \\
\end{array}$ & $\begin{array}{l}4 \\
25 \\
101 \\
\end{array}$ & $\begin{array}{l}3.1 \\
19.2 \\
77.7\end{array}$ & 2.64 & 0.267 \\
\hline $\begin{array}{l}\text { 4- Management responsibility } \\
\text {-Low } \\
\text {-Moderate } \\
\text {-High }\end{array}$ & $\begin{array}{l}58 \\
49 \\
23\end{array}$ & $\begin{array}{l}44.6 \\
37.7 \\
17.7\end{array}$ & $\begin{array}{l}3 \\
81 \\
46\end{array}$ & $\begin{array}{l}2.3 \\
62.3 \\
35.4\end{array}$ & 65.13 & $0.0001 *$ \\
\hline
\end{tabular}

*Significant $(\mathrm{P}<0.05)$ 


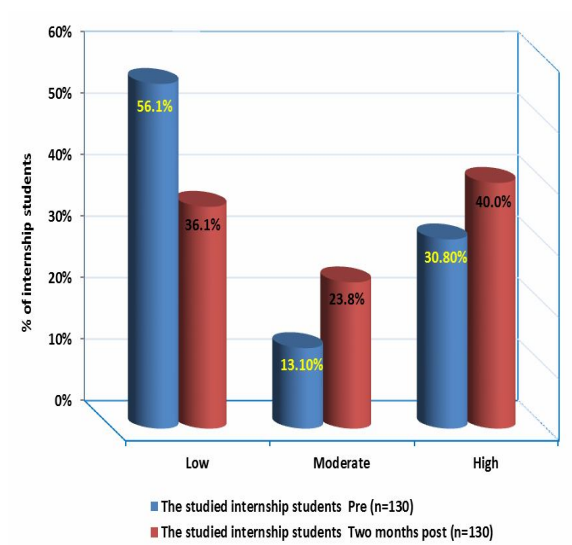

Figure (1): Total scoring grades of skills acquisition among the studied internship students at ICUs pre and two months post internship training experience $(n=130)$.

\section{Discussion:}

In this study (Table 1), present the distribution of the studied sample by their demographic characteristics, the table revealed the mean age of the studied sample was $21.66 \pm 0.90$. The majority of them $(69 \%)$ were single.

In table (2), we noticed that, the highest among the studied nurses intern after two months internship training experience is assisting in daily hygienic procedures it may be due to that this procedure done daily by staff nurse in ICU and critical care nursing staff play as a role model for nurses intern due to absence of preceptors in the hospitals. This finding agreed with Bland-Jones ${ }^{[8]}$ who reported that daily hygienic procedures in critically ill patients is imperative in reducing the risk of nosocomial infection and improving patient comfort and discharge outcomes.

This finding contradicted with Mahmoud ${ }^{[9]}$ who reported that less than quarter of the nurse intern have satisfactory performance score about daily hygienic procedures after internship training. This may be due to the ignorance of nurse intern and critical care nursing staff to the importance of daily hygienic care to the critically ill patients.

Prevention of nosocomial infection was the lowest score to

technical skills acquisition regarding the difference between pre and post two months internship training experience. This may be due to that lack of supplies in intensive care unit and lack of nurse's knowledge about the importance of aseptic technique so staff nurses don't follow aseptic technique and nurses acts as role model for nurse interns.

This finding was supported by Mahmoud [10] who reported that there is a low statistical significant difference in the item related to prevention of noso-comial infection after internship experience. This may be due to lacking of experience and training in aseptic technique principles, also it may be 
The impact of internship training year on nurse interns' etc....

due to facilities shortage at Ain Shams University hospital. In addition, Shin ${ }^{[11]}$ mentioned that nursing student stated that theory they had learned in university about aseptic technique were not practiced in the clinical setting by nurses and other clinical staff. This result goes with Ali ${ }^{[12]}$ who reported that the majority of nursing educators perceived that equipment and resources were adequate in the hospital.

In table (3), we noticed that, Implementation of care plan category was the highest score regarding managerial skills after two months training experience except item of family teaching. It is probably due to that nurses intern tend to give more priority to physical needs and there was no relatives in intensive care units according to policy of the hospital. Similar findings were reported by Hassan and El-Shimy [13] they found that highest percentage of nurse interns in different hospitals was perform the implementation of care plan with varying percentages.

This finding is disagreed with Kamel ${ }^{[14]}$ who showed that highest percentages of agreement among nurses intern for the all items which related to health education of patient and family as needed.This due to recent emphasis on active patient and family role in self care activities. Hence, through this role the nurse intern can help patient and families to develop the selfcare abilities that will enable them to maximize their functioning and quality of life.

Also, this finding is incongruence with Harris ${ }^{[15]}$ who stressed that teaching patients and their families is an inherent role of the professional nurse and is closely woven into everyday practice, and it is the responsibility of the nurse intern to assist patient in discrimination between actual health information and that information which is clearly false, misleading, and would cause incorrect health care decisions.

Data collection and analysis was the lowest score regarding managerial skills after two months internship training experience. It probably due to critical care nursing staff tend to give more priority to physical needs than managerial skills( data collection and analysis) in addition to the fact that critical care nursing staff play as a role model for our student due to absence of preceptors in hospital. Most of nurse interns think data collection and analysis is the responsibility of medical staff and they are responsible for nursing care only. In this respect, Hassan ${ }^{[16]}$ reported that the nurse intern had unclear and inadequate managerial skills. 


\begin{abstract}
Accordingly, Phipps et al [17] mentioned that the nurse intern should perform a complete physical assessment of the patients, which would include collecting data about the onset of disease and its progress. As asserted by Ellis and Hartley ${ }^{[18]}$ each nurse intern must demonstrate competence that meets minimum criteria in the performance of taking efficient and complete physical assessment. This is vital to construct a data base to formulate the nursing diagnosis and in order to delineate complete nursing actions.
\end{abstract}

\section{Recommendation:}

Based on the results of this study, it was recommended that, Cooperation between hospital nursing managers and nursing faculty members should be promoted to connect nurse interns to the real world of nursing with follow up for their performance to decrease the gap between theoretical education and practical implementation. Strict observation for the intern's performance from faculty member and hospital team. Internship commit members should be identified to every nurse intern.

\section{References:}

1.Dan forth D.A; and smith G.B; (2001): Hospital Based Case management: part II clinical pathways. Nursing spectrumcareer fitness on line .htm.

2. Died N., Nish G., and Coose C. (2000):

Performance expectations of associate degree nurse graduate within the first six months .Journal of nursing education; 39(7):302-307.

3.NACE, (2011): In Mahmoud, (2004) as the effect of internship year on the performance of nurse intern, A study at Faculty of Nursing at Zagazig University.

4.Wolper M., Martin G., (2005): Attention Mrtadata in Knowledge and learning management, in 6th ed, Graz,Austria.

5.Drab,S.L., (2011): Advanced practice internship article 44 available at http:// www.acp_accredit.org/deans/sta ndards.asp accessed at $25 / 3 / 2013$.

6.Carrfey and Curren, (1980): Orientation Professional Profile questionnaire.

7.Barbra et al, (2002): The scoring system of Orientation professional profile check list.

8. of internship training year on nurse intern skill Unpublished Master Thesis, Faculty of Nursing, Ain Shams University, Pp: 99.

9.Shin R. (2000): The meaning of the clinical learning experience of Korea nursing student. 
The impact of internship training year on nurse interns' ${ }^{\prime}$ etc....

Journal of Nursing Education
.39(6).
10.Ali, H.A.(2004): Positive and
negative aspects affecting
process in the Clinical setting
,Master thesis, Faculty of
Nursing Benha branch,Zagazig
University Pp 27 .
11.Hassan R., and El-Shimy H.M
(2001): The performance of
Nursing Interns Related to Basic
Nursing Procedures.
Unpublished Master Thesis,
Faculty of Nursing, Ain Shams
University, Pp: 117,120-122.

12. Kamel,F.F.,(2006): Study of internship year problems and its effect on intern-nurses satisfaction at Benha University hospital .Master thesis, Faculty of Nursing, Pp 100.
13.Harris k. (2004): Case applications in Nursing leadership and management, Delmar Learning: A division of Thomson Learning Inc, P.151.

14.Hassan R.M. (2004): Work related hazards facing nurseintern: A strategy for protection Faculty of Nursing Ain Shams University.

15.Phipps w., Monahan F., and Sand J., (2003): Medical Surgical Nursing, 7th ed., Toronto: Mosby Comp, Pp: 1363-1383.

16. Ellis J., and Hartley C. (2009): Nursing in Today's World. Trends, Issues and Management. 9th ed., Walters Kluwer HealthComp, Lippincott Williams\& Wilkins, New York,U.S.A, Pp: 323,481493. 